\title{
Analisa Sebaran Tutupan dan Indeks Mortalitas Terumbu Karang di Perairan Sekitar Selat Pagai Mentawai
}

\author{
Analysis of Coral's Cover and Coral's Mortality Index Around Pagai Strait Mentawai
}

\author{
*Herdiana Mutmainah ${ }^{1}$ dan Rani Santa Clara ${ }^{2}$ \\ ${ }^{1}$ Loka Penelitian Sumber Daya dan Kerentanan Pesisir Balitbang KP, KKP \\ ${ }^{2}$ Program Studi Oseanografi, Institut Teknologi Bandung \\ Komp. PPS Bungus, Jl. Raya Padang Painan KM 16, Telp/Fax. 0751-751458. \\ Teluk Bungus. Sumatera Barat. Indonesia. \\ *Email : herdianam@yahoo.com
}

\begin{abstract}
Abstrak
Terumbu karang hidup di perairan tropis yang sensitif akan perubahan lingkungan terutama suhu, salinitas, sedimentasi dan eutrofikasi. Selat Pagai, Mentawai terletak di Samudera Hindia antara Pulau Pagai Utara dan Pagai Selatan. Selat Pagai terletak di jalur tumbukan antar lempeng (Eurasia dan Indo-Australia) dengan aktifitas tektonik yang tinggi. Rangkaian peristiwa Tsunami Mentawai menyebabkan sebagian besar perairan di Kepulauan Mentawai rusak terutama terumbu karang. Penelitian ini bertujuan untuk mengetahui fenomena Coral Bleaching dan dampak Tsunami terhadap terumbu karang di sekitar Selat Pagai. Metode yang digunakan adalah Line Intercept Transect (LIT). Penelitian dilakukan pada April 2016 di sekitar Pulau Sijao-jao, Pulau Siruso dan Tunang Bulag. Pengamatan mencakup parameter arus, lingkungan perairan, persen tutupan karang hidup dan karang mati, alga, abiotik dan biota lain. Hasil pengukuran menunjukkan kecepatan arus 0,2 - 0,48 m/det. Beberapa parameter melebihi atau di bawah ambang batas, yaitu suhu, TDS dan salinitas. Parameter seperti $\mathrm{pH}$ dan kecerahan masih memenuhi ambang batas. Sijao-jao memiliki persen tutupan karang rata-rata yaitu 20,17\% (buruk) dan IM 0,767; Siruso dengan tutupan karang 30,45\% (sedang) dan IM 0,544; sedangkan Tunang Bulag memiliki tutupan karang 25,08\% (sedang) dan IM 0,451. Acropora sp. merupakan terumbu karang yang paling rentan terhadap bleaching.
\end{abstract}

Kata kunci : Indeks mortalitas, Pemutihan karang, Persen tutupan karang, Terumbu karang, Mentawai.

\begin{abstract}
Coral live in tropical waters that sensitive to environment changes, especially temperature, salinity, sedimentation and eutrophication. Pagai Strait at Mentawai is part of the Indian Ocean which lies between North Pagai and South Pagai Island. Pagai Strait island located in the region which is the path of collision between two plates (Eurasia and Indo-Australia) and high tectonic activities. Some Mentawai Tsunami led severely damaged to most of the Mentawai waters. This study aims to determine of Coral Bleaching phenomenon and the impact of Tsunami, to coral reefs in the Pagai Strait. The method is Line Intercept Transect (LIT) and held in April 2016. The study was conducted on Sijao-jao, Siruso and Tunang Bulag. Observations did on the current, parameters of waters, the percent cover of live coral and dead coral, algae, abiotic and other biota. The result of this research shows that current's velocity is $0,2-0,48 \mathrm{~m} / \mathrm{sec}$. Some parameters such as temperature, TDS and salinity out of range of the treshold. $\mathrm{pH}$ and visibility are still in the range. Sijao-jao has the percent of coral cover $20,17 \%$ (poor) and IM 0,767; Siruso with coral cover 30,45\% (moderate) and IM 0,544; while Tunang Bulag has coral cover $25,08 \%$ (moderate) and IM 0,451. Acropora sp. is the most vulnerable of coral bleaching.
\end{abstract}

Keywords: Coral, Coral's cover percentage, Mortality Index, Coral bleaching, Mentawai. 
Herdiana Mutmainah: Analisa Sebaran Tutupan dan Indeks Mortalitas Terumbu Karang di Perairan Sekitar Selat Pagai Mentawai

\section{Pendahuluan}

Pulau Pagai Utara terletak di Samudera Hindia pada koordinat $02^{\circ} 42^{\prime} 41^{\prime \prime}$ LS dan $100^{\circ} 05^{\prime} 31^{\prime \prime}$ BT; secara administrasi merupakan bagian dari Kabupaten Kepulauan Mentawai. Pulau Pagai Utara terdiri dari Kecamatan Pagai Utara dengan ibukota Saumangayak dan Kecamatan Sikakap dengan ibukota Sikakap. Luas
Kecamatan Pagai Utara adalah $342,02 \mathrm{~km}^{2}$ dan Sikakap 278,45 $\mathrm{km}^{2}$. Berdasarkan UU No.1 Tahun 2014, Pulau Pagai Utara termasuk pulau kecil karena luasnya kurang dari $2.000 \mathrm{~km}^{2}$. Tsunami pada tahun 2007 dan 2010 menyebabkan rusaknya sebagian besar pesisir dan ekosistem laut, diantaranya terumbu karang.

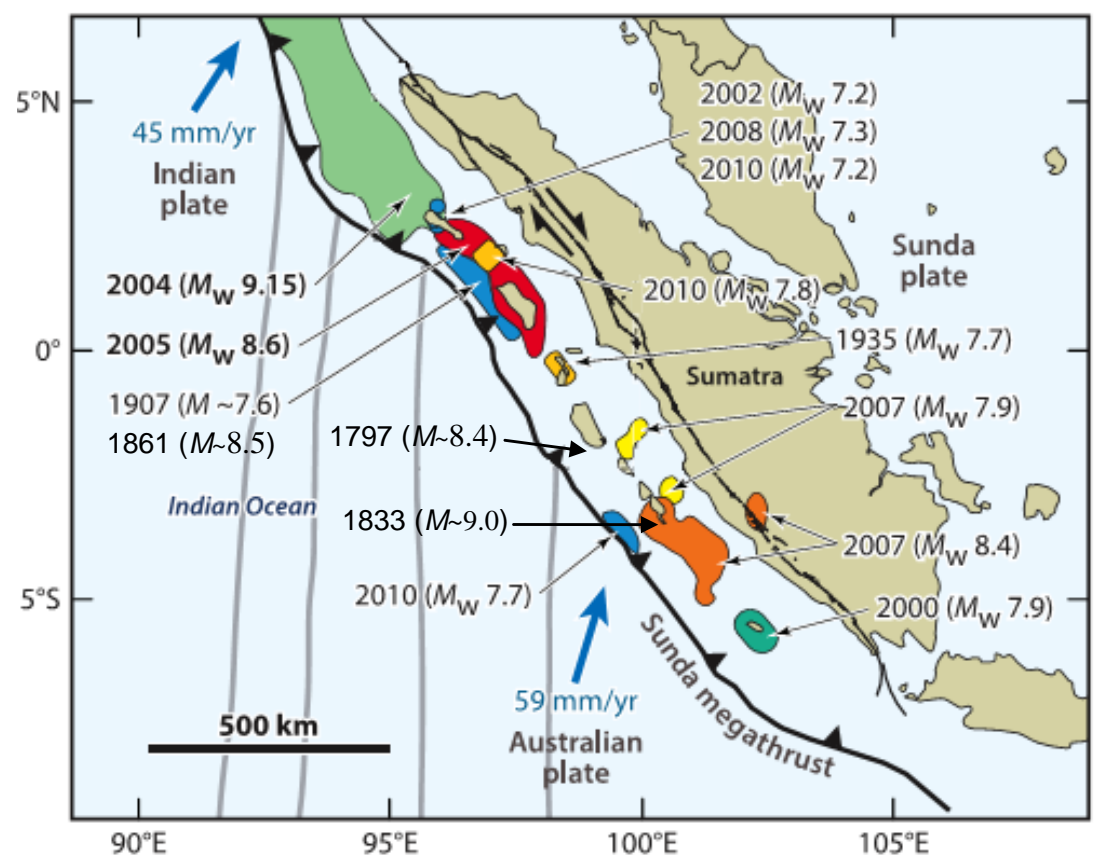

Gambar 1. Peta riwayat gempa dan tsunami di perairan Sumatera Barat dari Briggs et al. (2006),

Konca et al. (2008), Shearer dan Burgmann (2010), Hill et al. (2012), dan Meltzner et al. (2015).

Figure 1. Historical map of earthquake and tsunami in West Sumatra waters from Briggs et al. (2006),

Konca et al. (2008), Shearer and Brugmann (2010), Hill et al. (2012), and Meltzner et al. (2015).

Terumbu karang merupakan ekosistem yang unik dan spesifik karena pada umumnya terdapat di perairan tropis dan sangat sensitif terhadap perubahan lingkungan perairan terutama suhu, salinitas, sedimentasi dan eutrofikasi serta memerlukan kondisi perairan yang alami (Veron, 1995 dan Wallace, 1998). Terumbu karang mampu hidup pada kondisi thermal treshold dengan toleransi $1-2^{\circ} \mathrm{C}$ di atas rata-rata suhu/bulan yang jika melebihi itu maka akan terjadi bleaching massal (HoeghGoeldberg, 1999). Bleaching terjadi jika terdapat kenaikan suhu perairan $1-2^{\circ} \mathrm{C}$ selama 5-10 minggu (Buchheim, 1998). Naiknya suhu perairan menyebabkan stress dan disease (meningkatnya bakteri patogen) sehingga merusak hubungan polip dengan zooxanthellae. Lepasnya zooxanthellae menyebabkan karang kehilangan pigmen- pigmen warna untuk proses fotosintesis dan akhirnya menjadi putih.

Pendapat lain mengatakan bahwa bleaching adalah peristiwa terhambatnya pertumbuhan dan meningkatnya indeks kematian terumbu karang baik musiman ataupun massal. Diversitas terumbu karang dan dugaan kecepatan arus juga mempengaruhi tingkat bleaching (Douglas, 2003). Semakin tinggi diversitas, semakin rendah potensi bleaching demikian pula dengan arus karena pada arah dan kecepatan tertentu, arus dapat menyebabkan sirkulasi atau pertukaran massa air dan nutrien. Salinitas yang kurang dari 3240 ppm (Veron, 1986), badai atau banjir (Goreau, 1964; Egana dan DiSalvo, 1982), turbiditas yang tinggi (Glynn, 1996) serta sedimen dan nutrien (Goreau, 1992; Wilkinson dan Buddemeier, 1994) juga mempengaruhi 
terjadinya bleaching. Suhu optimal karang adalah $24-29^{\circ} \mathrm{C}$ dengan bleaching treshold yang spesifik untuk spesies yang berbeda-beda (Krupa, 1998). Hasil penelitian di laboratorium menunjukkan coral bleaching disebabkan oleh perubahan suhu yang ekstrim, tingkat radiasi yang tinggi, kondisi gelap yang berkepanjangan, logam (tembaga dan cadmium) dan bakteri patogen (HoeghGuldberg, 1999; Brown, 2000; Chalker, et al., 1988, Ben-Haim dan Rosenberg, 2002).

Predator seperti Acanthaster planci juga menyebabkan terjadinya bleaching (Moran, 1986). Bleaching massal dapat terjadi akibat perubahan iklim (kenaikan suhu dan muka air laut) serta dampak Badai El Nino (Stone et al.,1999). Komposisi substrat seperti pasir dan pecahan karang mati akibat Tsunami ditemukan di lokasi coral bleaching di Pulau Weh (Purbani dkk, 2014). Hasil penelitian LIPI pada tahun 2008 dan 2011 menyebutkan bahwa kategori persentase tutupan karang di Timur Selat Pagai adalah baik yaitu $60,93 \%$ (2008) dan 66,6\% (2011) dengan dasar perairan sekitar $15 \mathrm{~m}$. Kategori tutupan karang di Desa Sikakap (barat Sijaojao) tergolong jelek dengan persentase tutupan karang 6,70\% (2008) dan 8,17\% (2011) dengan dasar berupa patch reef di kedalaman $20 \mathrm{~m}$. Terjadi peningkatan luasan tutupan karang yang ditumbuhi Alga/DCA menjadi 70,93\% di Pulau Sitonggo, MTWL 84 seperti pada Gambar 2 (CRTC-LIPI, 2011).

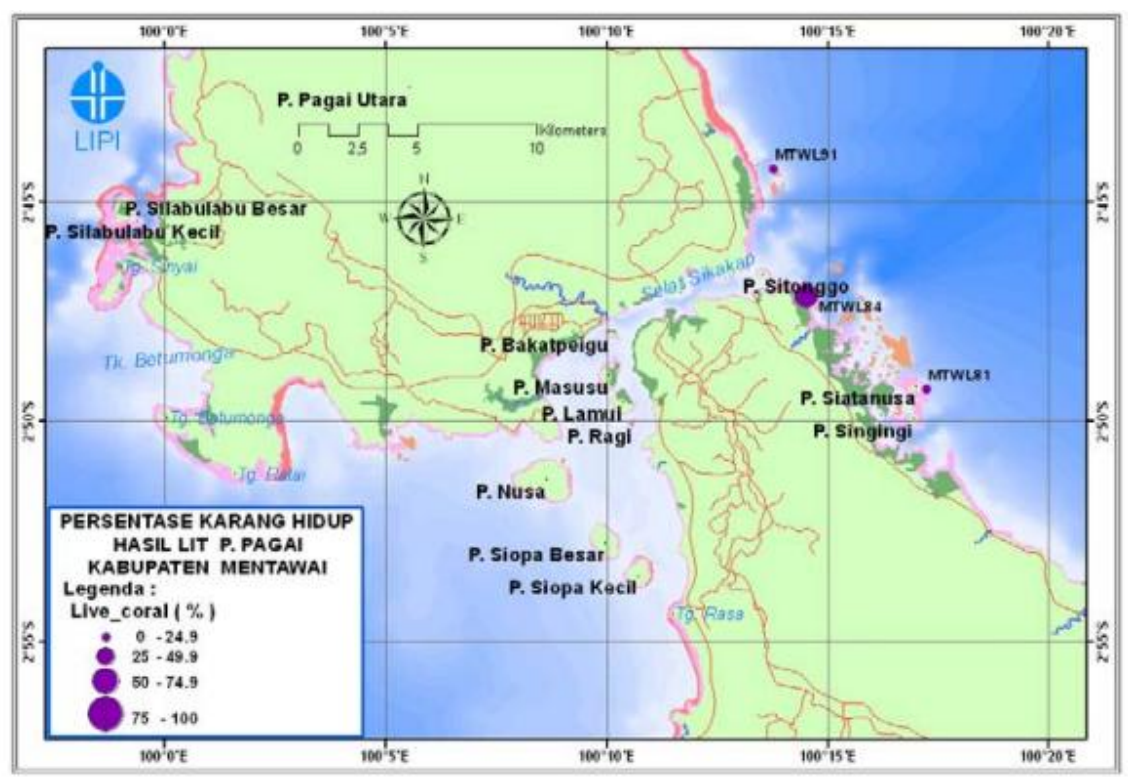

Gambar 2. Hasil penelitian LIPI terhadap tutupan karang di Pulau Pagai Tahun 2011

Figure 2. Research result from LIPI of coral's cover in Pagai Island 2011

Berdasarkan kondisi tersebut dan bencana Tsunami di Mentawai, 2010 maka penelitian ini bertujuan untuk mengetahui sebaran tutupan dan indeks terumbu karang di Selat Pagai.

\section{Bahan dan Metode}

Pengamatan terumbu karang di Pagai Utara dilakukan pada April 2016 menggunakan metode Line Intercept Transect (LIT) untuk menentukan komunitas bentik berdasarkan life form dalam satuan persen dan mencatat jumlah bentik yang ada di sepanjang garis transek. Komunitas karang dicirikan dengan menggunakan kategori lifeform (bentuk hidup) yang memberikan gambaran deskriptif mengenai morfologi komunitas karang. Komponen habitat dasar serta panjang transisi tutupan yang ditemukan sepanjang transek garis $10 \mathrm{~m}$ dikelompokkan menurut bentuk pertumbuhannya. Rumus dibawah digunakan untuk menghitung persentase tutupan karang (English et al., 1994) : 
Herdiana Mutmainah: Analisa Sebaran Tutupan dan Indeks Mortalitas Terumbu Karang di Perairan Sekitar Selat Pagai Mentawai

$$
\begin{gathered}
\% \text { tutupan karang }=\frac{\text { Panjang bentuk hidup }(\mathrm{cm})}{\text { panjang garis transek }} \times 100 \% \ldots \ldots . \text { (1) } \\
\text { Tabel 1. Kriteria Persen Tutupan Terumbu Karang } \\
\text { Table 1. Criteria of percentage coral reef's cover }
\end{gathered}
$$

\begin{tabular}{cc}
\hline Kategori & \% \\
\hline Buruk & $0-24,9$ \\
Sedang & $25-49,9$ \\
Baik & $50-74,9$ \\
Baik Sekali & $75-100$
\end{tabular}

Sumber : Keputusan Menteri Lingkungan Hidup No.4 Tahun 2001

Penilaian suatu kondisi kesehatan dari ekosistem terumbu karang tidak hanya berpatokan pada persentase tutupan karang saja, karena kemungkinan terjadi dua daerah yang memiliki persentase tutupan karang sama tingkat hidupnya namun mempunyai tingkat kerusakan yang berbeda. Tingkat kerusakan ini terkait dengan besarnya perubahan karang hidup menjadi karang mati. Rasio kematian karang dapat diketahui melalui indeks mortalitas karang dengan perhitungan (English $\begin{array}{lll}\text { et } & \text { al, }\end{array}$

$$
\text { Indeks Mortalitas }(I M)=\frac{\text { persen penutupan }(\text { karang mati })}{\text { persen penutupan }(\text { karang mati }+ \text { hidup })} \ldots \ldots
$$

Nilai indeks mortalitas yang mendekati nol menunjukkan bahwa tidak ada perubahan yang berarti bagi karang hidup, sedangkan nilai yang mendekati satu menunjukkan bahwa terjadi perubahan berarti dari karang hidup menjadi karang mati. Jika dikelompokkan, maka kategori kondisi IM adalah :

Tabel 2. Kategori Indeks Mortalitas Terumbu Karang

Table 2. Category of coral reef's mortality index

\begin{tabular}{cc}
\hline Kategori & IM \\
\hline Rendah & $0-0,249$ \\
Sedang & $0,25-0,499$ \\
Tinggi & $0,50-0,749$ \\
Tinggi Sekali & $0,75-100$ \\
\hline
\end{tabular}

Kondisi fisik dan kimia perairan yang diukur dibandingkan terhadap batas ambang yang telah ditetapkan dalam Keputusan Menteri Lingkungan Hidup No. 51 Tahun 2004 Lampiran 3 Tentang Baku Mutu Air Laut untuk Biota Laut.

Parameter lingkungan perairan diukur menggunakan alat Water Quality Checker (TOAA) dengan metode purposive samplingdan pengukuran di laboratorium kualitas air BARISTAND (Padang) sedangkan kecepatan arus diukur menggunakan ADCP yang diletakkan di selat Pagai selama 15 hari (2 - 18 April 2016). GPS digunakan untuk menandai koordinat lokasi (ground truthing). Adapun lokasi penelitian adalah seperti dalam Gambar 3. 
Tabel 3. Baku Mutu Air Laut untuk Biota Laut Table 3.Quality Standart of Sea Water for Marine Biota

\begin{tabular}{|c|c|c|}
\hline No & Parameter & Biota Laut \\
\hline 1 & $\mathrm{pH}$ & $7.0-8.5$ \\
\hline \multirow[t]{4}{*}{2} & Suhu $\left({ }^{\circ} \mathrm{C}\right)$ & $28-30$ \\
\hline & Coral : $28-30$ & \\
\hline & Mangrove : 28 - 32 & \\
\hline & Lamun : $28-30$ & \\
\hline \multirow[t]{4}{*}{3} & Salinitas $(\% 00)$ & $33-34$ \\
\hline & Coral : 33 - 34 & \\
\hline & Mangrove : s/d 34 & \\
\hline & Lamun : 33 - 34 & \\
\hline 4 & Kekeruhan/Turbidity (NTU) & $<5$ \\
\hline 5 & DO (mg/L) & $>5$ \\
\hline \multirow[t]{4}{*}{6} & Kecerahan (m) & $>5 \mathrm{~m}$ \\
\hline & Coral : > 5m & \\
\hline & Mangrove : - & \\
\hline & Lamun : > 3m & \\
\hline \multirow[t]{4}{*}{7} & TDS (mg/L) & 20 \\
\hline & Coral : 20 & \\
\hline & Mangrove : 80 & \\
\hline & Lamun : 20 & \\
\hline
\end{tabular}

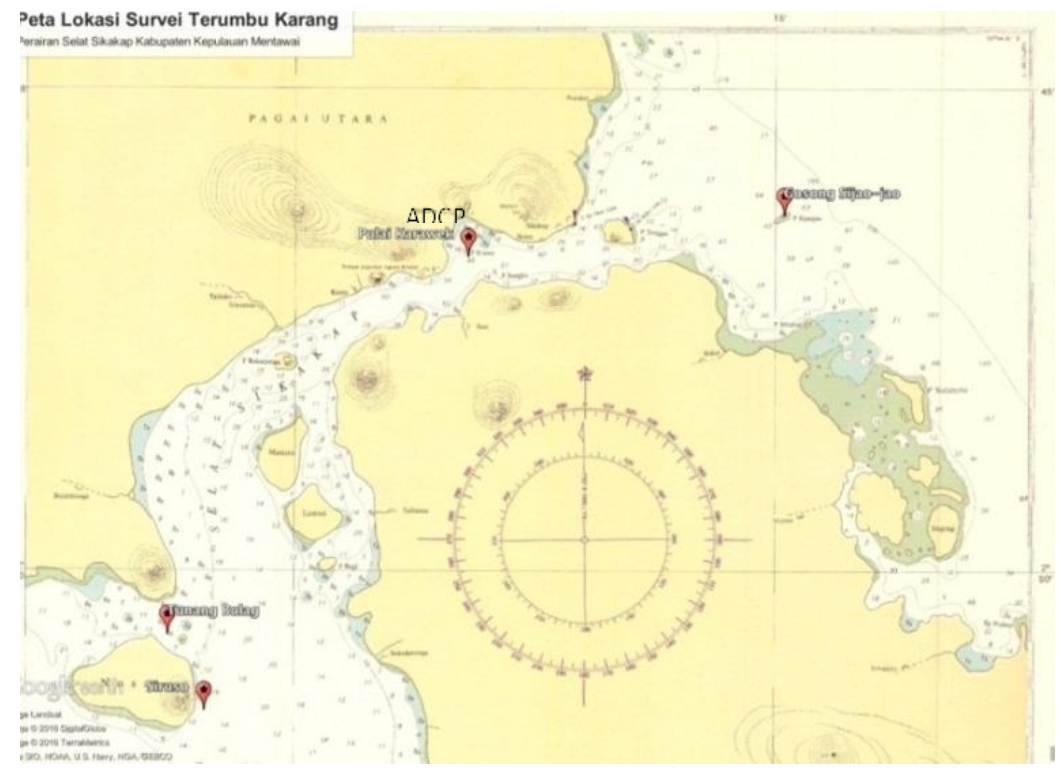

Gambar 3. Peta Lokasi Survey Terumbu Karang di Pagai Utara Figure 3. Map of Coral Reef Survey's Location in North Pagai

\section{Hasil dan Pembahasan}

Gosong Sijaojao

Lokasi ini merupakan gosong dengan kemiringan dasar bervariasi antara $30^{\circ}$ hingga $90^{\circ}$. Morfologi dasar perairan berupa karang keras hingga kedalaman 16 meter.
Substrat terdiri dari patahan karang mati hingga kedalaman 5 meter dengan kemiringan $30^{\circ}$ dan pada kedalaman lebih dari 5 meter, substrat berupa patahan karang bercampur pasir. Tutupan karang keras adalah 30,47\% yang terdiri dari $17,53 \%$ Acropora dan $12,93 \%$ Non Acropora. Jenis karang Acropora terdiri 
Herdiana Mutmainah: Analisa Sebaran Tutupan dan Indeks Mortalitas Terumbu Karang di Perairan Sekitar Selat Pagai Mentawai

dari Acropora Branching (ACB) dan Acropora Digitate (ACD). Non Acropora terdiri dari Coral Massive (CM), Coral Encrusting (CE) dan Coral Submassive (CS). Fenomena bleaching tampak pada Dead Coral (DC) sebesar 8,2\%.

Pada Site 1, taxon dengan tutupan karang paling tinggi adalahAcropora sp. yaitu sebesar $0.38 \%$ dan Seriatopora Hystryx sebesar
0,39\% sedangkan yang paling rendah adalah Sponge dan Gallaxea sp. sebesar 0.07\%. Pada site 2, taxon Acropora sp.dan Favia sp.banyak ditemui sebesar $0.54 \%$.Komunitas paling sedikit adalah Favites sp. yaitu $0.04 \%$. Site 3 menunjukkan Pocillopora sp.merupakan komunitas paling banyak yaitu $0.42 \%$ dan yang paling rendah adalah Acropora sp.yaitu $0.05 \%$.

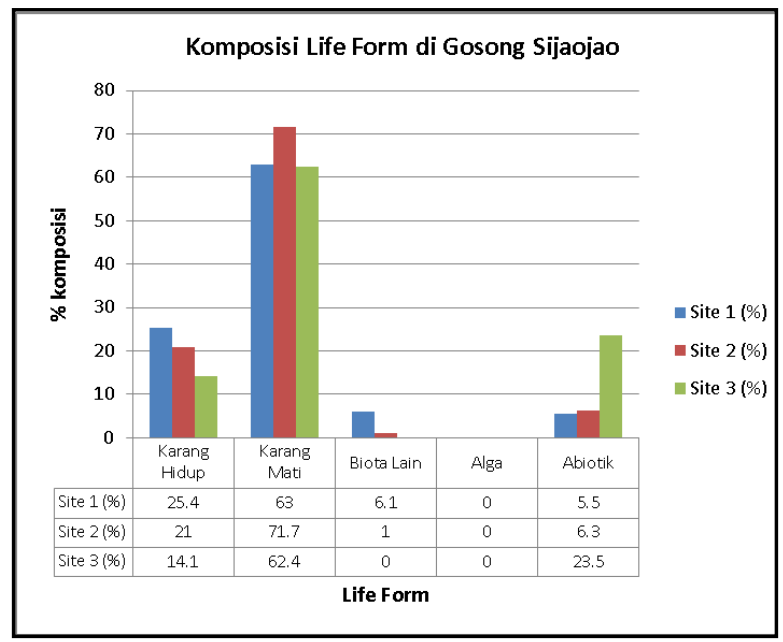

Gambar 4. Komposisi Life Form Ketiga Site di Gosong Sijaojao.

Figure 4. Life Form Composition of the Three Sites in Gosong Sijaojao

Berdasarkan Gambar 4, tutupan karang hidup di Site 1 (25,4\%); Site 2 (21\%); site $3(14,1 \%)$ dengan rata-rata tutupan karang untuk ketiga site di Gosong Sijaojao adalah 20,17\% atau kategori buruk.

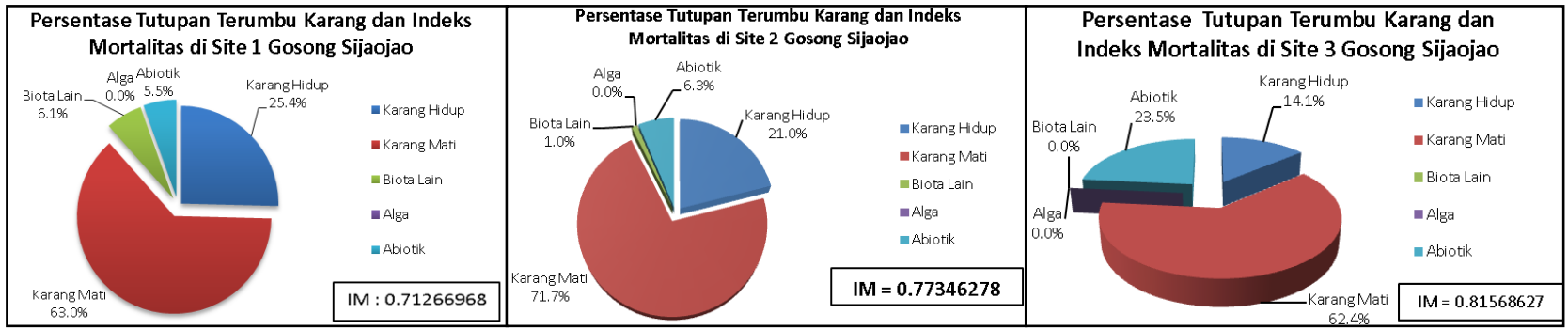

(a) Tutupan Karang dan IM Site 1

(b) Tutupan Karang dan IM Site 2

(c) Tutupan Karang dan IM Site 3

Gambar 5. Persentase Tutupan Terumbu Karang danIndeks Mortalitas Ketiga Site di Gosong Sijaojao

Figure 5. Percentage of Coral Reef's Cover and Mortality Index of Three Sites in Gosong Sijaojao

Berdasarkan Gambar 5, Indeks Mortalitas (IM)

di Site $1(0,713 \%)$; Site $2(0,774)$; site $3(0,816)$ dengan IM rata-rata untuk ketiga site di Gosong Sijaojao adalah 0,767 dan tergolong tinggi sekali. 
Tabel 4. Parameter Kualitas Perairan Gosong Sijaojao

Table 4. Water Quality Parameter in Gosong Sijaojo Waters

\begin{tabular}{cccccccc}
\hline $\begin{array}{c}\text { Kedalaman } \\
(\mathbf{m})\end{array}$ & $\mathbf{p H}$ & $\begin{array}{c}\text { DO } \\
(\mathbf{m g} / \mathbf{L})\end{array}$ & $\begin{array}{c}\text { Suhu } \\
\left({ }^{\circ} \mathrm{C}\right)\end{array}$ & $\begin{array}{c}\text { Salinitas } \\
(\%)\end{array}$ & $\begin{array}{c}\text { TDS } \\
(\mathbf{m g} / \mathbf{L})\end{array}$ & $\begin{array}{c}\text { Turbiditas } \\
(\mathbf{N T U})\end{array}$ & $\begin{array}{c}\text { Kecerahan } \\
(\mathbf{m})\end{array}$ \\
\hline Kedalaman 0 m & 8,18 & 4,05 & 30,8 & 32,3 & 53,2 & 0,58 & 9,5 \\
Kedalaman 6 m & 7,46 & 6,38 & 30,7 & 32,7 & 53,2 & 0,74 & \\
\hline
\end{tabular}

Kondisi lingkungan perairan Gosong Sijaojao diindikasikan dari beberapa parameter (Tabel 4) yang dibandingkan dengan ambang batas untuk biota laut (Kepmen LH No. 51 Th.2004) sehingga didapat $\mathrm{pH}$ pada kisaran 7,46-8,18 (7,0-8,5); DO 4,05-6,38 mg/L (>5); Turbiditas 0,58-0,74 NTU $(<5)$; suhu 30,7-30,8 ${ }^{\circ} \mathrm{C}$ (28-30); salinitas 32,3-32,7 \% (33-34), TDS 53,2 mg/L (20) dan kecerahan 9,5 m (>5). Berdasarkan hal tersebut maka parameter yang masih memenuhi ambang batas adalah $\mathrm{pH}$, DO, kecerahan dan turbiditas/kekeruhan. Sedangkan parameter yang melebihi atau di bawah ambang batas adalah suhu (melebihi $0,75^{\circ} \mathrm{C}$ ), TDS (melebihi 33,2 $\mathrm{mg} / \mathrm{L}$ ) dan salinitas (rata-rata dibawah $0,5 \%$ ).

\section{Pulau Siruso}

Pantai berpasir putih, pecahan karang dan ke arah dasar merupakan karang keras. Kemiringan dasar perairan sekitar $20^{\circ}$ dengan substrat dasar berupa patahan karang mati yang sudah ditutupi sedimen lumpur tipis dan pasir. Karang keras hidup ditemukan mulai dari tempat yang dangkal sampai kedalaman 10 meter. Persentase tutupan karang keras hidup adalah 0,46\% dengan komposisi 17,53\% Acropora dan 12,93\% Non Acropora. Jenis karang acropora terdiri dari Acropora Branching (ACB) dan Acropora Tabulate (ACT). Non Acropora terdiri dari Coral Branching (CB), Coral Encrusting (CE) dan Coral Submassive (CS). Pada saat pengambilan data disemua stasiun pengamatan ditemukan fenomena bleaching, Dead Coral (DC) $22,2 \%$.

Pada Site 1, taxon Pocillopora sp. memiliki persen tutupan karang yang paling tinggi sebesar $0.42 \%$ dan paling rendah adalah Acropora sp. yaitu sebesar $0.05 \%$. Site 2, Acropora sp. sebesar $0.52 \%$ dan yang paling rendah adalah Teripang yaitu sebesar $0.05 \%$. Site 3, Acropora sp. memiliki persen tutupan karang yang paling tinggi yaitu $0.69 \%$ dan yang paling rendah adalah Seriatopora hystryx yaitu sebesar $0.07 \%$.

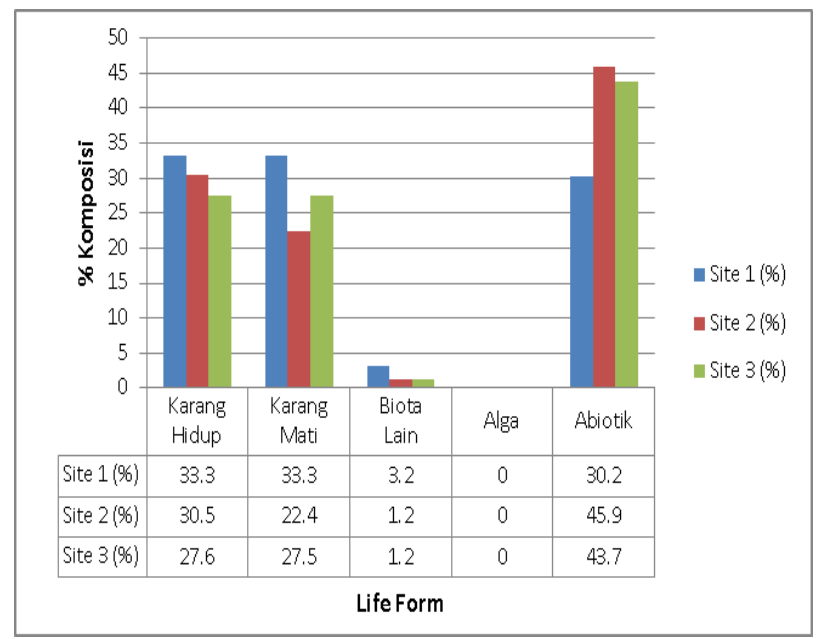

Gambar 6. Komposisi Life Form Ketiga Site di Pulau Siruso

Figure 6. Composition of ThreeSites of Life Forms in Siruso Island 
Herdiana Mutmainah: Analisa Sebaran Tutupan dan Indeks Mortalitas Terumbu Karang di Perairan Sekitar Selat Pagai Mentawai

Berdasarkan Gambar 6, tutupan karang hidup di Site $1(33,3 \%)$; Site $2(30,5 \%)$; site $3(27,6 \%)$ dengan rata-rata tutupan karang untuk ketiga site di Pulau Siruso adalah $30,45 \%$ atau kategori sedang.

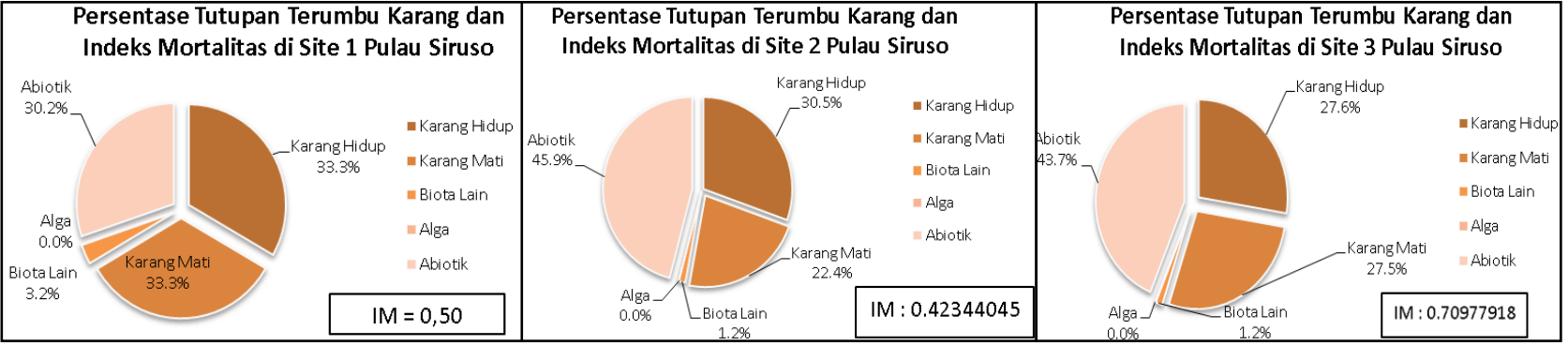

(b) Tutupan Karang dan IM Site 1

(b) Tutupan Karang dan IM Site 2

(c) Tutupan Karang dan IM Site 3

Gambar 7. Persentase Tutupan Terumbu Karang danIndeks Mortalitas Ketiga Site di Pulau Siruso Figure 7. Percentage of Coral Reef's Cover and Mortality Index of Three Sites in Siruso Island

Indeks Mortalitas (IM) di Site $1(0,50 \%)$; Site $2(0,423)$; site $3(0,709)$ dengan IM rata- rata untuk ketiga site di Pulau Siruso adalah 0,544 dan tergolong tinggi (Gambar 7).

Tabel 5. Parameter Kualitas Perairan Pulau Siruso

Table 5. Parameter of Water Quality inSiruso's Island

\begin{tabular}{cccccccc}
\hline $\begin{array}{c}\text { Kedalaman } \\
(\mathbf{m})\end{array}$ & $\mathbf{p H}$ & $\begin{array}{c}\text { DO } \\
(\mathbf{m g} / \mathbf{L})\end{array}$ & $\begin{array}{c}\text { Suhu } \\
\left({ }^{\circ} \mathbf{C}\right)\end{array}$ & $\begin{array}{c}\text { Salinitas } \\
(\% / 00)\end{array}$ & $\begin{array}{c}\text { TDS } \\
(\mathbf{m g} / \mathbf{L})\end{array}$ & $\begin{array}{c}\text { Turbiditas } \\
(\mathbf{N T U})\end{array}$ & $\begin{array}{c}\text { Kecerahan } \\
(\mathbf{m})\end{array}$ \\
\hline Kedalaman 0 m & 8,39 & 4,66 & 30,6 & 31,9 & 52,4 & 0,41 & 10,5 \\
Kedalaman 6 m & 8,41 & 8,24 & 30,5 & 32,3 & 52,1 & 0,54 & \\
\hline
\end{tabular}

Kondisi lingkungan perairan Pulau Siruso dibandingkan dengan ambang batas untuk biota laut (Kepmen LH No. 51 Th.2004) didapat $\mathrm{pH} 8,39-8,41$ (7,0-8,5); DO 4,66-8,24 $\mathrm{mg} / \mathrm{L}(>5)$; Turbiditas 0,73-3,11 NTU (<5); suhu 30,5-30,6 ${ }^{\circ} \mathrm{C}$ (28-30); salinitas 31,9-32,3 $\%$ (33-34), TDS 52,1-52,4 mg/L (20) dan kecerahan 10,5 m (>5). Berdasarkan hal tersebut maka parameter yang masih memenuhi ambang batas adalah $\mathrm{pH}$, DO, kecerahan dan turbiditas/kekeruhan. Sedangkan parameter yang melebihi atau di bawah ambang batas adalah suhu (melebihi $0,55^{\circ} \mathrm{C}$ ), TDS (melebihi $32,2 \mathrm{mg} / \mathrm{L}$ ) dan salinitas (rata-rata dibawah $1 \% 00$ ).

\section{Tunang Bulag}

Tunang Bulag memiliki pantai berpasir putih. Kemiringan dasar perairan sekitar $15^{\circ}$. Substrat dasar sampai kedalaman 7 meter berupa karang keras ditutupi lumpur tipis, sedangkan pada kedalaman lebih dari 7 meter substrat berupa lumpur, pasir dan patahan karang mati. Persentase karang keras hidup sebesar 25,6\% yang terdiri dari 6,6\% Acropora dan 19,00\% Non Acropora. Jenis karang Acropora terdiri dari Acropora Branching (ACB) dan Acropora Tabulate (ACT). Non Acropora terdiri dari Coral Branching (CB), Coral Massive (CM), Coral Encrusting (CE) dan Coral Submassive (CS). Coral bleaching ditandai dengan Dead Coral (DC) sebesar $8,2 \%$.

Life form di Site 1 banyak dijumpai taxon Montipora sp. dengan persen tutupan karang yang paling tinggi sebesar $0.58 \%$, sedangkan paling rendah adalah Leptoseris sp. dan Acropora sp. sebesar $0.05 \%$. Site 2 terdapat Sponge dengan persen tutupan karang paling tinggi yaitu $0.5 \%$ dan yang paling rendah Acropora sp. sebesar $0.04 \%$. Pada Site 3, Montipora sp. memiliki persen tutupan karang yang paling tinggi sebesar $0.72 \%$ dan yang paling rendah adalah Porites sp. sebesar $0.07 \%$. 


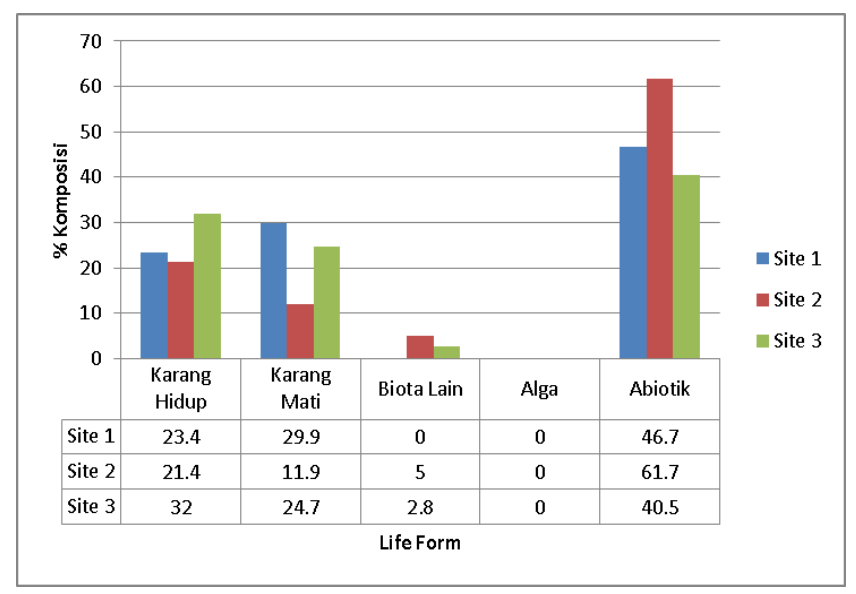

Gambar 8. Komposisi Life Form Ketiga Site di Tunang Bulag

Figure 8. Composition of Life Form of Three Sites in Tunang Bulag

Berdasarkan Gambar 8, tutupan karang hidup di Site $1(23,4 \%)$; Site $2(21,4 \%)$; site 3 $(32,0 \%)$ dengan rata-rata tutupan karang untuk ketiga site di Tunang Bulag adalah 25,08\% atau kategori sedang.

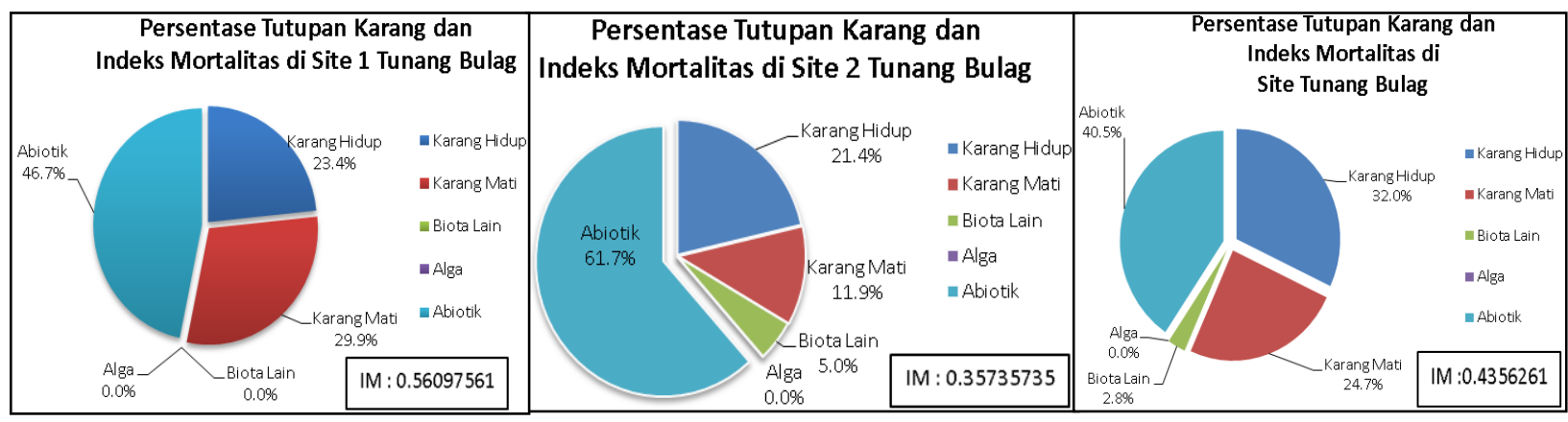

(c) Tutupan Karang dan IM Site 1

(b) Tutupan Karang dan IM Site 2

(c) Tutupan Karang dan IM Site 3

Gambar 9. Persentase Tutupan Terumbu Karang danIndeks Mortalitas Ketiga Site di Tunang Bulag

Figure 9. Percentage of Coral Reef's Cover and Mortality Index of Three Sites in Tunang Bulag

Indeks Mortalitas (IM) di Site $1(0,561 \%)$; Site $2(0,357)$; site $3(0,436)$ dengan IM rata- rata untuk ketiga site di Tunang Bulag adalah 0,451 dan tergolong sedang (Gambar 9).

Tabel 6. Parameter Kualitas Perairan Tunang Bulag

Table 6. Parameter of Waters Quality in Tunang Bulag

\begin{tabular}{cccccccc}
\hline $\begin{array}{c}\text { Kedalaman } \\
(\mathbf{m})\end{array}$ & $\mathbf{p H}$ & $\begin{array}{c}\text { DO } \\
(\mathbf{m g} / \mathbf{L})\end{array}$ & $\begin{array}{c}\text { Suhu } \\
\left({ }^{\circ} \mathrm{C}\right)\end{array}$ & $\begin{array}{c}\text { Salinitas } \\
(\%)\end{array}$ & $\begin{array}{c}\text { TDS } \\
(\mathbf{m g} / \mathbf{L})\end{array}$ & $\begin{array}{c}\text { Turbiditas } \\
(\mathbf{N T U})\end{array}$ & $\begin{array}{c}\text { Kecerahan } \\
(\mathbf{m})\end{array}$ \\
\hline Kedalaman 0 m & 8,42 & 5,79 & 31 & 32,9 & 54,1 & 3,11 & 7,5 \\
Kedalaman 6 m & 8,35 & 9,72 & 30,7 & 33 & 54,2 & 0,73 & \\
\hline
\end{tabular}

Kondisi lingkungan perairan Tunang Bulag (Tabel 4) dibandingkan dengan ambang batas untuk biota laut (Kepmen LH No. 51 Th.2004) didapat $\mathrm{pH}$ pada kisaran 8,35-8,42 (7,0-8,5); DO 5,79-9,72 mg/L (>5); Turbiditas 0,73-3,11 NTU (<5); suhu $30,7-31{ }^{\circ} \mathrm{C}(28-30)$; salinitas 32,9-33 \%00 (33-34), TDS 54,1-54,2 mg/L (20) dan kecerahan 7,5 m (>5). Berdasarkan hal tersebut maka parameter yang masih memenuhi ambang batas adalah $\mathrm{pH}, \mathrm{DO}$, kecerahan, salinitas dan turbiditas/kekeruhan. Sedangkan parameter yang melebihi ambang batas adalah suhu (melebihi $0,85^{\circ} \mathrm{C}$ ) dan TDS (melebihi 34,15 mg/L). 
Herdiana Mutmainah: Analisa Sebaran Tutupan dan Indeks Mortalitas Terumbu Karang di Perairan Sekitar Selat Pagai Mentawai

Persentase Tutupan dan Indeks Mortalitas Terumbu Karang

Sebaran terumbu karang di ketiga lokasi (Gambar 10) tampak lebih banyak tersebar (patchy reefs) di sisi Timur Selat Pagai sedangkan di sisi barat, terumbu karang mengelilingi pulau-pulau kecil yang ada (fringing reefs)

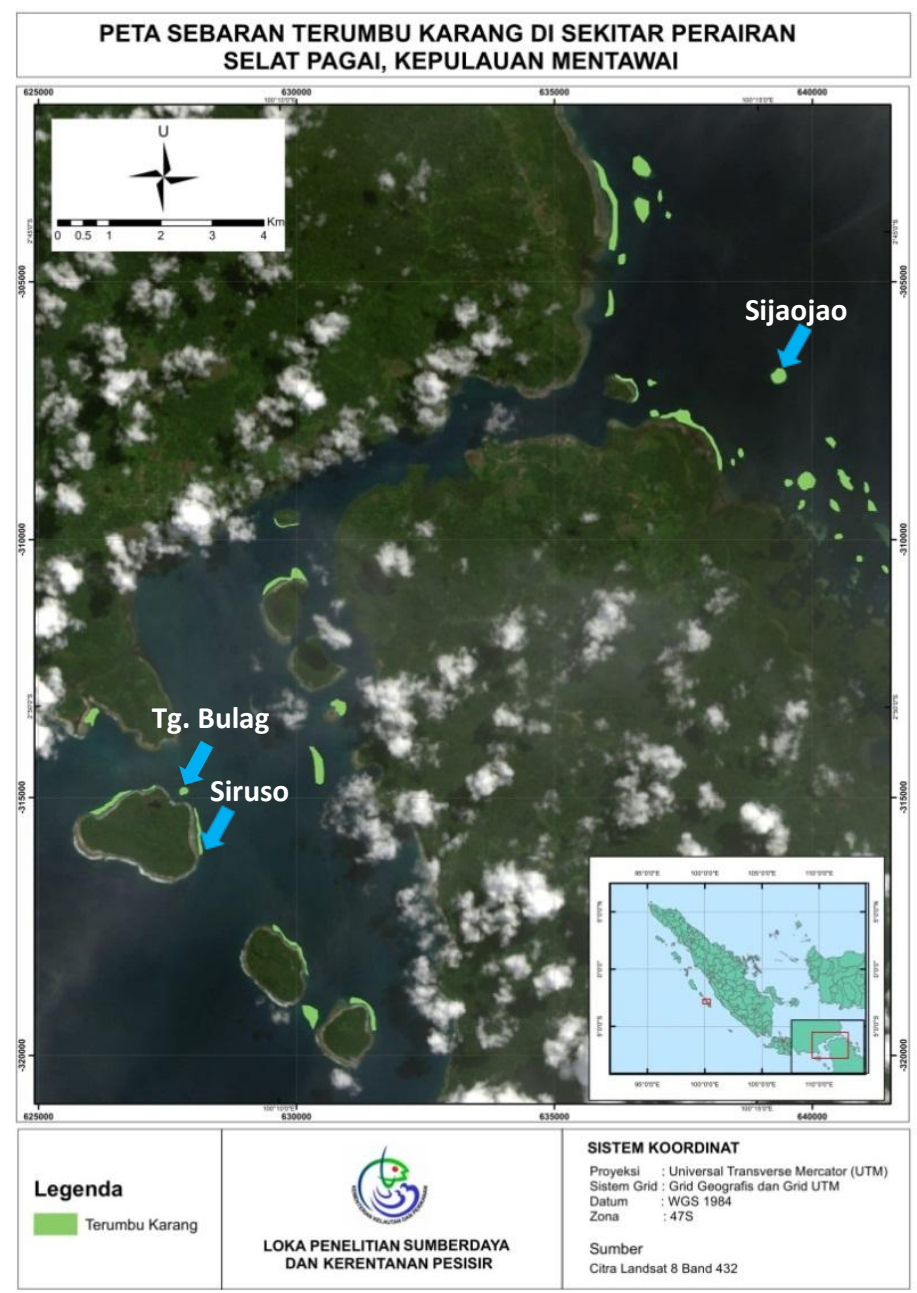

Sumber : Modifikasi Citra Landsat 8 (Hasil Analisa, 2016)

Gambar 10. Peta Sebaran Terumbu Karang di Perairan Sekitar Selat Pagai

Figure 10. Map of Coral Reef's Distribution in Waters around Pagai Strait

Berdasarkan rata-rata persentase tutupan karang hidup dan Indeks Mortalitas ketiga lokasi (Gambar 11) tampak bahwa Pulau Siruso memiliki persentase tutupan karang yang lebih tinggi dibanding yang lain sedangkan untuk Indeks Mortalitas, Gosong Sijaojao menempati posisi tertinggi. Pada Gosong Sijaojao, semakin sedikit persentasetutupan karang hidup maka semakin besar Indeks Mortalitas terumbu karang di lokasi tersebut. Secara umum di ketiga lokasi didapat bahwa pada persentase tutupan karang sebesar 25-30,5\% menunjukkan IM 0,45-0,50 sedangkan pada tutupan karang 20\%, menunjukkan IM 0,78 . 


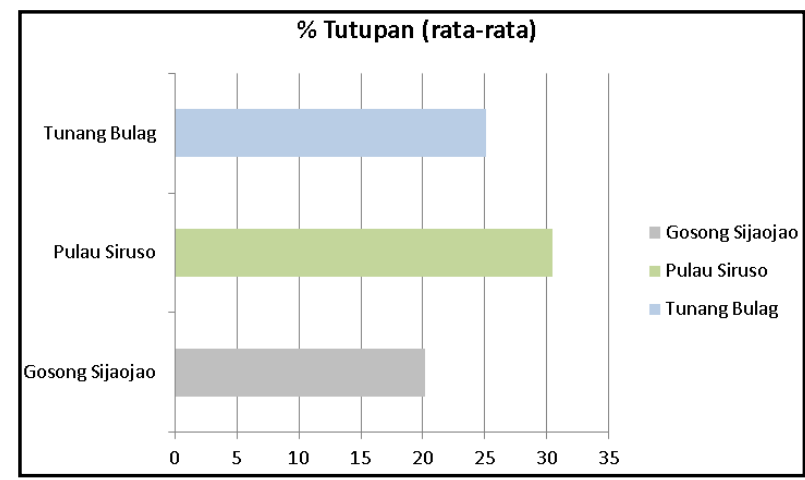

(a) Persentase Tutupan Terumbu Karang

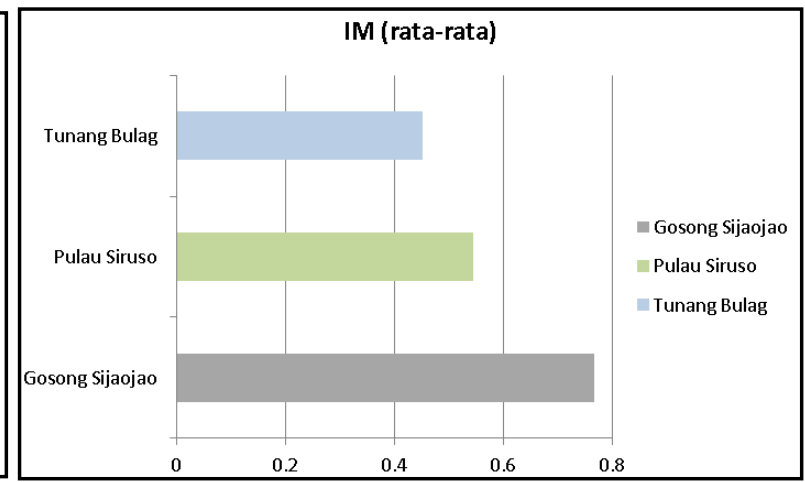

(b) Indeks Mortalitas Terumbu Karang

Gambar 11. Persentase Tutupan dan Indeks Mortalitas Rata-rata Terumbu Karang di 3 Lokasi (Gosong Sijaojao, Pulau Siruso dan Tunang Bulag)

Figure 11. The Percentage of Coral Cover and the Average Mortality Index of Coral Reef's in three different locations (Gosong Sijaojao, Siruso Island and Tunang Bulag)

\section{Sebaran Parameter Kualitas Perairan}

Sebaran parameter kualitas perairan di ketiga lokasi (Gosong Sijaojao, Pulau Siruso dan Tunang Bulag) adalah seperti Gambar 12. Oksigen terlarut (DO) tampak hampir sama di semua lokasi. $\mathrm{pH}$, salinitas dan temperatur di sebelah timur yaitu Sijaojao lebih tinggi dibanding Siruso dan Tg. Bulag. Sedangkan untuk TDS dan turbiditas, sebelah barat yaitu Siruso dan Tunang Bulag lebih tinggi dibanding Sijaojao. TDS dan turbiditas yang lebih tinggi di Siruso dan Tunang Bulag menjadi indikasi bahwa lokasi ini memang pernah terkena hantaman Tsunami yang cukup parah. Hal ini didukung dengan kondisi substrat berupa karang patah dan pecahan karang mati serta lumpur dan pasir yang menyebabkan tingginya nilai TDS (sedimen terlarut) dan kekeruhan di perairan Siruso dan
Tunang Bulag. Pecahan karang mati dan lumpur merupakan tipikal jenis substrat di perairan yang terkena Tsunami, Pulau Weh (Purbani dkk., 2014).

\section{Kecepatan Arus}

Arus di Selat Pagai di kedalaman 5,5 meter cenderung bergerak horisontal pada kecepatan 0,3-0,5 $\mathrm{m} / \mathrm{det}$ disertai percepatan. Pada kedalaman 15,5 meter, arus bergerak ke segala arah baik horisontal maupun vertikal, cenderung bersudut dengan kecepatan 0,2 hingga $0,48 \mathrm{~m} / \mathrm{det}$ (Gambar 13). Kecepatan arus diukur pada $2-18$ April 2016 menggunakan ADCP. Arus di Siruso dan Tunang Bulag lebih cepat dibanding Sijaojao karena merupakan perairan terbuka dan berbatasan langsung dengan Samudera Hindia, sedangkan Sijaojao terletak di lokasi yang terlindung, yaitu Selat Mentawai.

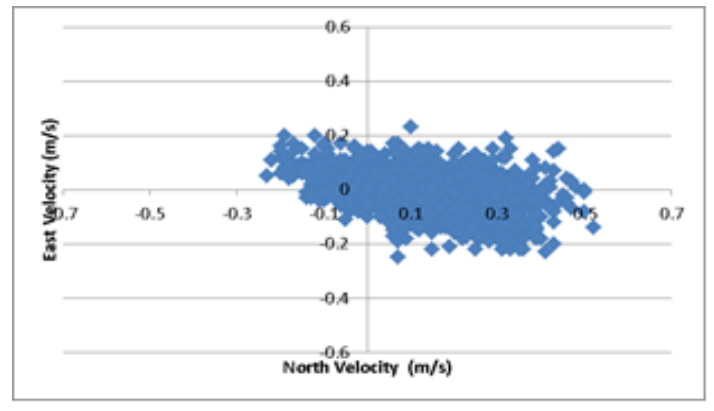

(a) Kecepatan arus kedalaman 5,5 m

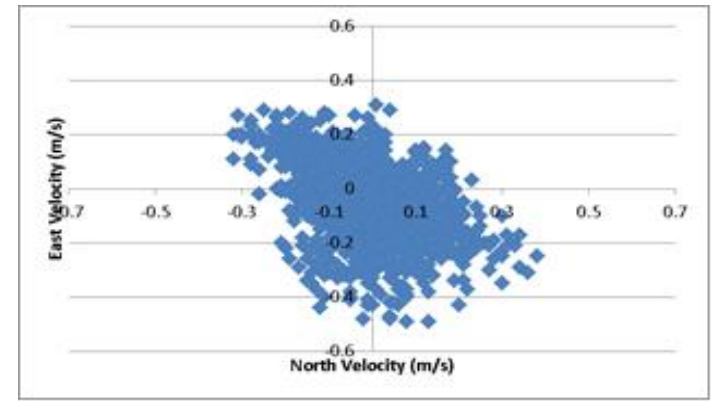

(b) Kecepatan arus pada kedalaman 15,5 m

Gambar 12. Kecepatan arus pada kedalaman 5,5 dan 15,5 meter di Selat Pagai

Figure 12. Curent velocity at 5.5 and 15.5 meters depth in Pagai Strait 
Herdiana Mutmainah: Analisa Sebaran Tutupan dan Indeks Mortalitas Terumbu Karang di Perairan Sekitar Selat Pagai Mentawai

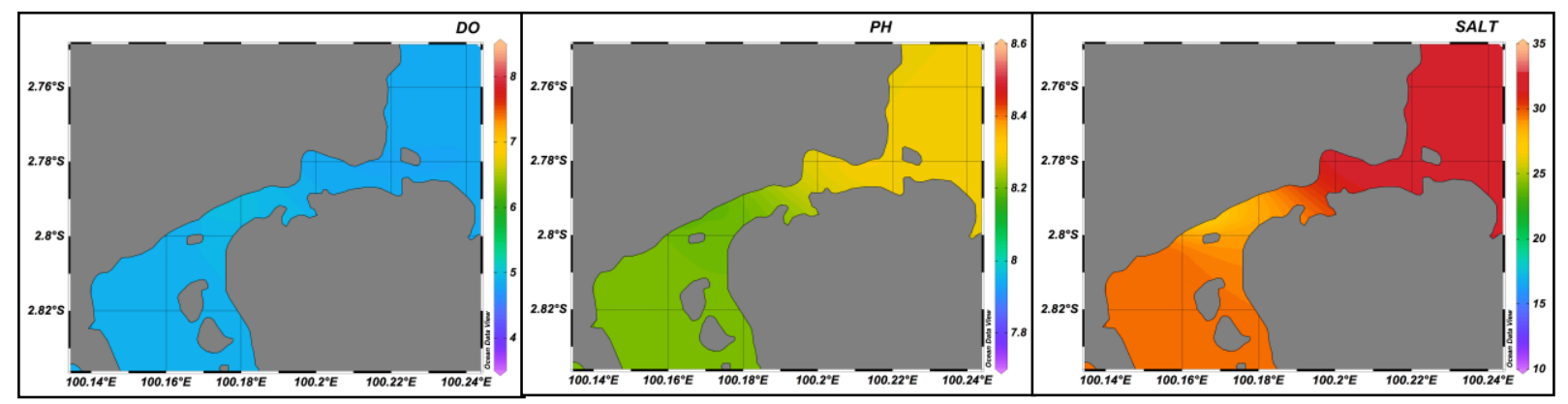

(a) Dissolved Oxygen

(b) $\mathrm{pH}$

(c) Salinitas

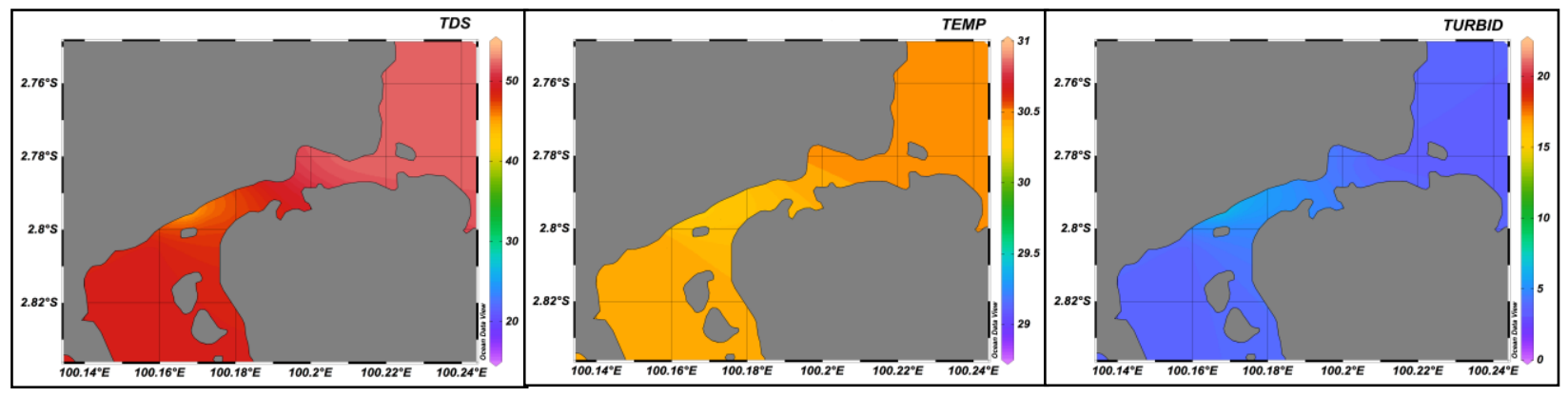

(d) Sedimen terlarut/TDS

(e) Temperatur

(f) Turbiditas

Gambar 13. Sebaran Parameter Kualitas Air Rata-rata di 3 Lokasi(Gosong Sijaojao, Pulau Siruso dan Tunang Bulag)

Figure 13. Distribution of average Water Quality Parameter in three Locations (Gosong Sijaojao, Siruso Island and Tunang Bulag)

Gambar 14 di bawah menunjukkan kecepatan arus rata-rata di kedalaman 1,5 dan 15,5 meter

yang berkisar antara 0,15 hingga $0,25 \mathrm{~m} / \mathrm{det}$ disertai percepatan.

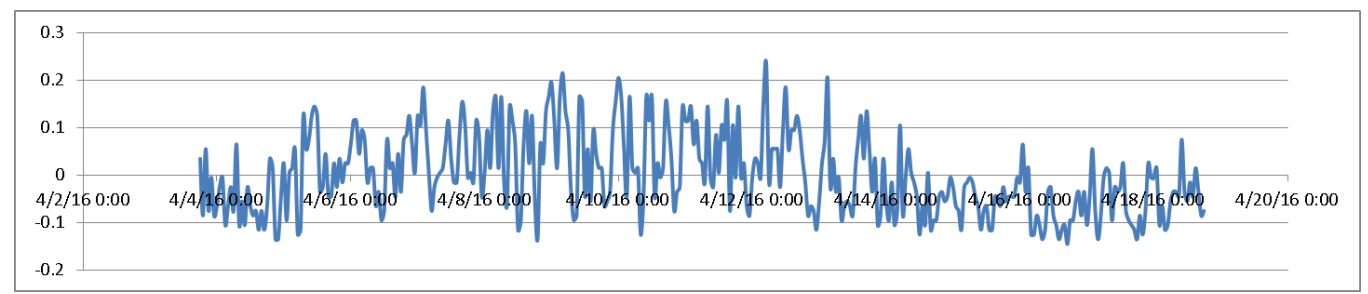

Gambar 14. Kecepatan arus rata-rata selama 15 hari pada kedalaman 1,5;5,5; dan 15,5meter di Selat Pagai ( ADCP, 2-18 April 2016)

Figure 14. Average of Current Velocity for 15 days at 1.5;5.5; and 15.5 meters depth in Pagai Strait (ADCP, April $2^{\text {nd }}$ to $18^{\text {th }}, 2016$ )

Jenis Terumbu Karangyang mengalami Bleaching dan Komposisi Substrat

Berdasarkan pengamatan terhadapkondisi terumbu karang dan substrat di ketiga lokasi, Acropora,sp merupakan jenis yang paling rentan mengalami bleaching. Beberapa jenis Non Acropora seperti Fungia dan Montipora juga ditemukan mengalami bleaching di
Gosong Sijaojao (Gambar 15a dan 15c). Gambar 15j, 15k dan 151 menunjukkan kondisi substrat ketiga lokasi. Tingkat diversitas terumbu karang di lokasi pengamatan, yaitu Sijaojao lebih beragam sekitar 10 jenis, sedangkan di Siruso dan Tunang Bulag hanya 6 jenis. 


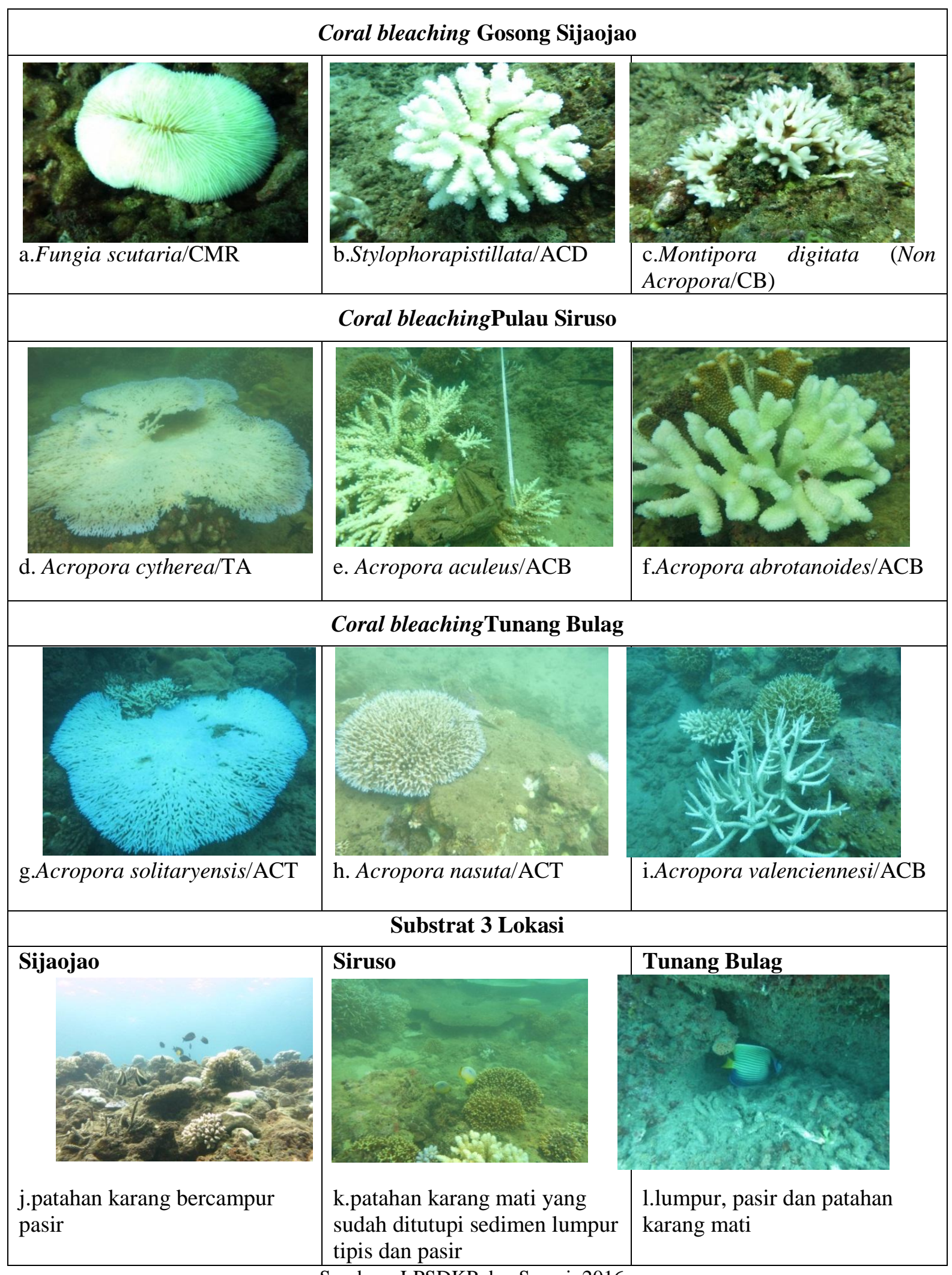

Sumber : LPSDKP dan Sanari, 2016

Gambar 15. Jenis coral bleaching dan komposisi substrat di 3 lokasi(Gosong Sijaojao, Pulau Siruso dan Tunang Bulag)

Figure 15. Type of Coral Bleaching and Substrate Composition in ThreeLocations (Gosong Sijaojao, Siruso Island and Tunang Bulag) 
Herdiana Mutmainah: Analisa Sebaran Tutupan dan Indeks Mortalitas Terumbu Karang di Perairan Sekitar Selat Pagai Mentawai

Berdasarkan hasil analisa secara keseluruhan terhadap parameter terumbu karang, lingkungan perairan dan kondisi substrat maka Gosong Sijaojao memiliki tutupan karang hidup yang rendah dengan tingkat mortalitas yang tinggi. Hal ini mungkin disebabkan karena tingginya aktivitas penduduk dan dampak Tsunami yang terjadi secara beruntun pada tahun 2007. Sijaojao merupakan lokasi yang terkena Tsunami pada tahun 2007 di gempa pertama $(7,9 \mathrm{Mw})$ dan secara bersamaan, ketiga lokasi juga terkena Tsunami pada tahun 2007 di gempa kedua $(8,4 \mathrm{Mw})$. Siruso dan Tunang Bulag terakhir terkena Tsunami pada tahun $2010 \quad(7,7 \mathrm{Mw})$. Walaupun diversitas terumbu karang di Sijaojao beragam namun jenis terumbu karang yang dijumpai berukuran kecil sehingga mudah mengalami bleaching.Tingkat kejernihan di Sijaojao mungkin disebabkan kondisi perairan yang berangsur pulih pasca Tsunami 9 tahun.

\section{Simpulan}

1. Hasil pengukuran menunjukkan suhu di lokasi pengamatan sedikit melebihi ambang batas $\left(28-30^{\circ} \mathrm{C}\right)$ yaitu sekitar $30-30,5^{\circ} \mathrm{C}$; TDS melebihi ambang batas $(<20 \mathrm{mg} / \mathrm{L})$ yaitu 43-53 $\mathrm{mg} / \mathrm{L}$; salinitas dibawah ambang batas $(33-34 \%$ ) yaitu $30-32 \%$; $\mathrm{pH}$ masih memenuhi ambang batas $(7-8,5)$ yaitu 8-8,4 sedangkan kecerahan atau visibilitas masih memenuhi ambang batas (>5 m) yaitu 5-8 m. Sijaojao memiliki nilai rata-rata persen tutupan karang 20,17\% (buruk) dan IM 0,767 (tinggi sekali); Siruso dengan tutupan karang 30,45\% (sedang) dan IM 0,544 (tinggi); sedangkan Tunang Bulag memiliki tutupan karang 25,08\% (sedang) dan IM 0,451 (sedang).

2. Acropora sp. merupakan terumbu karang yang banyak dijumpai di Sijao-jao dan Siruso sedangkan di Tunang Bulag, Montipora sp. dan Sponge lebih banyak dibanding Acropora sp. Tingkat tutupan karang terhadap ketiga lokasi tergolong dalam kategori buruk hingga sedang. IM tergolong sedang hingga tinggi sekali. Kondisi tutupan terumbu karang di keseluruhan siteyang tergolong sedang terdapat di Siruso.

3. Jenis Acropora sp. merupakan terumbu karang paling rentan terhadap bleaching di keseluruhan lokasi. Fungia dan Montipora ditemukan bleaching di Gosong Sijaojao.Diperlukan waktu pemulihan lingkungan perairan yang cukup lama setelah Tsunami ( $>6$ tahun). Terumbu karang ukuran kecil lebih rentan terhadap bleaching dibanding jenis tabular. Suhu, TDS, salinitas dan arus sangat mempengaruhi terjadinya coral bleaching di perairan sekitar Selat Pagai.

\section{Ucapan Terima Kasih}

Ucapan terima kasih disampaikan kepada Balitbang Kementerian Kelautan dan Perikanan (Balitbang KKP) di Jakarta, Loka Penelitian Sumber Daya dan Kerentanan Pesisir (LPSDKP KKP) di Bungus, Balai Pengelolaan Sumberdaya Laut dan Pesisir (BPSPL KKP) di Padang, Tim Selam Sanari (Padang), Institut Teknologi Bandung, Universitas Gadjah Mada, Institusi Perguruan Tinggi di Sumatera Barat, Pemerintah Daerah Provinsi Sumatera Barat, Pemerintah Daerah Kabupaten Kepulauan Mentawai (Dinas Kelautan dan Perikanan Kab. Mentawai, Bappeda Kab. Mentawai, BPBD Kab. Mentawai, Dinas Lingkungan Hidup dan Kehutanan Kab. Mentawai) dan lain-lain yang terlibat secara langsung maupun tidak langsung dalam penelitian ini.

\section{Daftar Pustaka}

Buchheim J. 1998. Coral reef bleaching. Marine Biology Learning Center Publications.

http://www.marinebiology.org/coralblea ching.htm Diakses pada tanggal 26 Oktober 2016.

Briggs, R.W., Sieh, K., Meltzner, A.J., Natawidjaja, D., Galetzka, J., Suwargadi, B., Hsu, Y.-j, Simons, M., Hananto, N., Suprihanto, I., Prayudi, D., Avouac, J.-P., Prawirodirdjo, L., Bock, Y. 2006. Deformation and slip along the sunda mega-thrust in the great 2005 nias-simeulue earthquake. Science 311. 1897-1901. http://dx.doi.org/10.1126/science.11226 02.

Douglas AE. 2003. Coral bleaching-how and why? Marine Pollution Bulletin 46. 385-392. Doi:10.1016/S0025326X(03)00037-7. www.elsevier.com/locate/marpolbul. 
English S, Wilkinson C, \& Baker V. 1994. Survey manual for tropical marine resources, $\quad 2^{\text {nd }}$ edition. Australian Institut of Marine Scienc. 390 pp.

English S, Wilkinson C, Baker V. 1998. Survey manual for tropical marine resources. Townsville: Australian Institute of Marine Science.

Glynn, P.W 1996. Coral reef bleaching: facts, hypotheses and implications. Global Change Biology 2 : 495-509.

Hoegh-Guldberg, 0. 1999. Climate change, coral bleaching and the future of the world's coral reefs. Greenpeace: Sydney (Australia), 28 pp.

http://dx.doi.org/10.1016/j.marpolbul.20 04.02.017.

Keputusan Menteri Negara Lingkungan Hidup Nomor : 51 Tahun 2004 tentang Baku mutu air laut (Link : http://www.menlh.go.id). Tanggal akses 10 Oktober 2016.

Konca, A.O., Avouac, J.-P., Sladen, A., Meltzner, A.J., Sieh, K., Fang, P., Li, Z., Galetzka, J., Genrich, J., Chlieh, M., Natawidjaja, D.H., Bock, Y., Fielding, E.J., Ji, C., Helmberger, D.V. 2008. Partial rupture of a locked patch of the sumatra megathrust

during the 2007. Earthquake sequence. Nature $456 . \quad \mathrm{p}: 631-635$. http://dx.doi.org/10.1038/nature.07572.

Krupa J. Coral bleaching and the affect of temperature change on coral reef predator-prey interactions. http://www.resnet.wm.edu/jxshix/math345/juliann-CoralBleaching.ppt. Diakses pada tanggal 26 Oktober 2016.

Laporan Coremap II monitoring terumbu karang kecamatan samukop, bosua dan sikakap kabupaten mentawai. 2011. Coral Reef Information and Training Centre (CRTC) - LIPI. Jakarta.

Laporan Coremap II monitoring terumbu karang mentawai (samukop, bosua dan sikakap). 2008. Coral Reef Information and Training Centre (CRTC) - LIPI. Jakarta.

Laporan Coremap studi baseline ekologi kabupaten mentawai. 2004. Coral Reef Information and Training Centre (CRTC) - LIPI. Jakarta.

Nybakken, J.W. 1988. Biologi laut : suatu pendekatan ekologi (alih bahasa dari Marine biology : an ecologycal approach, Oleh : M. Eidman, Koesoebiono, D.G. Bengen, M.Hutomo, dan S. Sukardjo). PT Gramedia. Jakarta.

Peter J. Mumby, William Skirving, Alan E. Strong, John T. Hardy, Ellsworth F. LeDrew, Eric J. Hochberg, Rick P. Stumpf, Laura T. David. 2004. Remote sensing of coral reefs and their physical environment. Marine Pollution Bulletin 482004 : 219-228.

Purbani D, Kepel TL, Takwir A. 2014. Kondisi terumbu karang di pulau weh pasca bencana mega tsunami. Jurnal Manusia dan Lingkungan. Vol.21 No.3 November 2014 : 331-340.

Suharsono. 1996. Jenis-jenis karang yang umum dijumpai di perairan Indonesia. Puslitbang Oseanologi - LIPI. Jakarta.

Tomascik, T., Mah, J.A., Nontji, A., Moosa, K.M., 1997. The ecologycal of the indonesian seas part II. Periplus Edition.

Tyler R. L. Christensen, 2008. Coral bleaching, satellite observations, and coral reef protection.http://www.eoearth.org/articl e/Coral_bleaching,_sat:ellite_observatio ns_and_coral_reef_protection. Diakses pada tanggal 26 Oktober 2016.

Undang-Undang No.1 Tahun 2014 tentang Perubahan Atas UU No.27 Tahun 2014 tentang Pengelolaan Wilayah Pesisir dan Pulau-pulau Kecil.

Veron JEN. 1995. Coral in space and time. Townsville: Australian Institute of Marine Science. 